Teknomekanik

Vol.3, No.1, May 2020, pp. $9 \sim 17$

e-ISSN: $2621-8720$ p-ISSN: 2621-9980

\title{
The Variation Effect of Electric Current Toward Tensile Strength on Low Carbon Steel Welding with Electrode E7018
}

\author{
M. Agung Pratomo, Jasman, Nelvi Erizon \& Yolli Fernanda \\ Jurusan Teknik Mesin, Fakultas Teknik, Universitas Negeri Padang, Indonesia
}

\begin{tabular}{l} 
Article Info \\
\hline Article history: \\
Received January $18^{\text {th }}, 2020$ \\
Revised March $11^{\text {th }}, 2020$ \\
Accepted April $25^{\text {th }}, 2020$ \\
\hline
\end{tabular}

Keywords:

Electric Current

SMAW

Low Carbon Steel

Electrode

Tensile Test

\begin{abstract}
The strength of the welding result is strongly influenced by several factors, one of which is the selection of high current. This study aims to determine the effect of high current of welding on the strength of low carbon steel welding joints. The process of welding the material uses the open $V$ seam connection type. The variations of the high current used were $80 \mathrm{~A}, 100 \mathrm{~A}$ and $130 \mathrm{~A}$. The specimen used was a carbon steel plate with code of 1.0038 with thickness of $8 \mathrm{~mm}$ and the electrode used was the E7018 electrode with diameter of $3.2 \mathrm{~mm}$. The strength of the welding results is influenced by arc voltage, amount of current, welding speed, amount of penetration and electric polarity. Determination of the amount of current in metal joints using arc welding affects the work efficiency and welding materials. Based on the research, it was found that welding using high current of 100 ampere produced the highest tensile strength value of all test specimens that were given welding treatment and good penetration results.
\end{abstract}

\section{Corresponding Author:}

M. Agung Pratomo,

Jurusan Teknik Mesin, Fakultas Teknik, Universitas Negeri Padang,

Jln. Prof. Dr. Hamka Air Tawar, Padang (25131), Sumatera Barat, Indonesia

Email: Muhamadagungpratomo@gmail.com

\section{INTRODUCTION}

Welding is a metallurgical bond in a metal or metal alloy joint which is carried out in a melting state. Based on this, it can be further explained that welding is a local joint of several metal rods using heat energy [1]. Welding is the process of joining the material which results in the fusion of the material by heating it to the right temperature with or without the use of a filler [2]. Welding is a metal joining process in which the metal becomes one due to welding heat, with or without the influence of pressure and with or without filler metal [3]. Welding has a very important role in the engineering and repair of metals that are used by humans, besides, in today's construction, many welding elements involve, especially in the engineering field [4]. The widespread use of the welding process is due to low cost, relatively fast implementation, lighter weight and more varied forms of construction [5]. From some of the opinions above, it can be concluded that welding work is to join two or more metal parts using heat energy [6]. The welding process involves steel plates made of iron and carbon crystals according to their microstructure with a certain shape and direction, the metal plates are heated until they melt. When the edges of the metal plates are joined together, a joint is formed [7].

Shield Metal Arc Welding (SMAW) is a welding process in which the alloying of metals is generated through heat from an electric arc that arises between the ends of the electrodes wrapped in the metal surface being welded [8]. The factor that affects the welding result is the welding procedure, which is planning for implementation which includes how to make a weld construction according to the plan and specifications by determining all the things needed in the implementation such as welding equipments, welding machines and safety tools [9]. Welding production factors are the manufacturing schedule, the manufacturing process, the tools and materials required, the order of execution, the preparation of welding (including: welding machine selection, the appointment of the welder, the electrode selection, the use of the seam type) [1]. SMAW welding is widely applied in constructions that use iron or steel as a material for manufacture [10]. Examples of SMAW welding applications in the construction sector include building bridges, multi-storey building construction, pipe industry, storage tank industry, pressure vessels, and structural industries such as shipping, 
transportation, heavy equipment and so on [4]. The widespread use of this welding technology is due to the fact that the joints are lighter with a simpler process, so that the costs required are cheaper. This advantage causes welding joints to be used as a substitute for rivet and bolt joints in machine structures and designs [11].

Welding involves various variables such as time, temperature, electrodes, power input and welding speed which will affect the final properties of the weld metal [13]. The most likely result of the welding process is the occurrence of weld cracks due to the occurrence of diffusion hydrogen and residual stress [15]. Diffusion hydrogen is caused when the weld metal melts, and it absorbs a large amount of hydrogen which is released by diffusion at low temperatures because at that temperature the solubility of hydrogen decreases [16]. The sources of absorbed hydrogen are water and organic substances contained in the flux and parent metals [15]. In addition, the tensile strength value is influenced by the increasing temperature of the material due to the gauze process, this indicates that the welded joint will be vulnerable to brittleness than the base metal and will also cause residual stress in the material [14]. residual stress is the occurrence of greater voltage surges due to changes in the properties of the material in the connection, especially in the heat affected area or HAZ (Heat Affected Zone), because the area is a metal area adjacent to the weld metal area which during the welding process experiences a thermal cycle of heating and rapid cooling resulting in decreased tensile strength and hardness at the weld joint [1]. In addition, the decrease in tensile strength can be attributed to the presence of voids and other defects that occur as a result of high welding currents which can also cause a decrease in tensile strength [12].

The strength of the welds is influenced by the arc voltage, the amount of current, the welding speed, the penetration magnitude and the electric polarity [17]. Determination of the amount of current in the joining of metals using arc welding affects the efficiency of work and welding materials [18]. In addition to the polarity of the determining factor which is one of the parameters in welding, namely a clean surface will produce a much stronger welded joint, surface oxides must be removed because they can become trapped in frozen metal [19]. So that it is possible to have a weld defect that causes a reduction in the strength of the weld metal, therefore a test is needed so that the resulting data can be valid [10]. Welding joints are a critical component because failures that occur in welding will have fatal consequences, to avoid this the acceptable standard of welding results is increasingly enhanced [20]. This acceptance standard represents the minimum weld quality based on a test specimen welded containing multiple discontinuities [21]. Carbon steel with code 1.0038 is used for this study because it accounts for about $90 \%$ of total ordinary carbon steel and is widely applied because of its economic value, excellent weld ability, good mechanical and physical properties which can be accepted by many applications [22]. The purpose of testing is to determine the quality of certain products or specimens, while the purpose of the inspection is to determine certain quality standards. In short, the purpose of testing and inspection is to guarantee the quality and to give confidence in the construction being welded. Therefore, the use of a control system in arc welding can eliminate much of the "guessing work" often used by welders to determine welding parameters for a given task [23]. This study uses the SMAW welding method with variations of electric current 80 Ampere, 100 Ampere, 130 Ampere using a manual arc welding machine (SMAW) DC (direct current) and electrodes measuring $3.2 \mathrm{~mm}$ using seam $\mathrm{V}$. The process of this research discusses about how the effect of variations in welding current on the tensile strength of low carbon steel as a result of SMAW welding using E7018 electrodes.

\section{METHOD}

The research method used is the experimental research method. The research object to be studied is carbon steel with a code of 1.0038 with thickness of $8 \mathrm{~mm}$ as a result of SMAW welding using the E7018 brand electrode with diameter of $3.2 \mathrm{~mm}$. The connection used is an open seam V connection which is welded with three variations of the welding current, namely $80 \mathrm{~A}, 100 \mathrm{~A}, 130 \mathrm{~A}$, and each variation of the current has three specimens that are tested using the Universal Testing Machine.

Table 1 : Tensile Testing Machine Specifications

\begin{tabular}{cc}
\hline Tipe & WE-1000 \\
\hline Tahun & 2000 \\
Buatan & China \\
Kapasitas & $1000 \mathrm{kN}$ \\
No. Serial & 1057 \\
\hline
\end{tabular}

Journal homepage: http://teknomekanik.ppj.unp.ac.id

DOI: https://doi.org/10.24036/tm.v3i1.5572 
Welded joints that will be used in this study are joints in the form of an open seam with angle of $60^{\circ}$. The seam joint $\mathrm{V}$ is used to join metal or plates with thickness of $6-20 \mathrm{~mm}$ with a seam angle of $50^{\circ}$, the root distance of 0-2 $\mathrm{mm}$ and the root height of 0-3 $\mathrm{mm}$ [24].
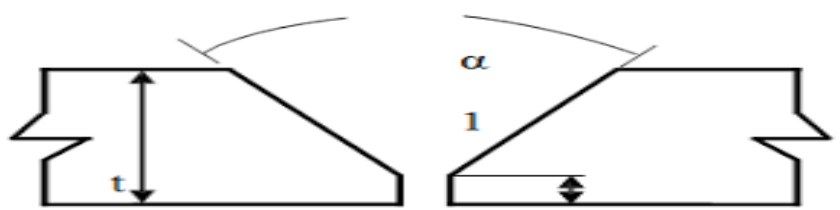

Figure 1 : The seam V [24].

Figure 1 illustrates the shape of the work unit that will undergo the welding process using seam V. The groove weld used in welding is divided into three parts; full penetration weld without retaining plate, full penetration weld with retaining plate, partial penetration weld. Therefore in the welding process the choice of connection type is very important and must be selected based on needs and uses. The form of the test specimen to be used in tensile testing is as follows:

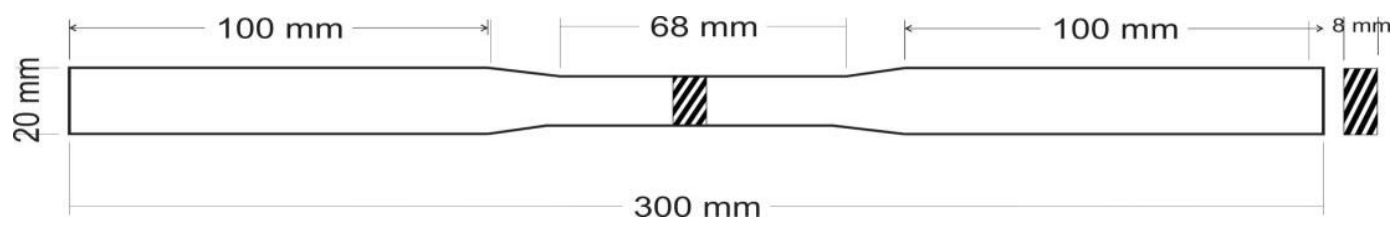

Figure 2 : Dimensions of ASTM E8 Tensile Test Specimen [25]

\section{SPECIMEN}

The test specimen used is carbon steel with code 1.0038 which is given welding treatment using magnitude of welding current about $80 \mathrm{~A}, 100 \mathrm{~A}$, and $130 \mathrm{~A}$. The following is a picture of carbon steel with code 1.0038 after being formed into a tensile test specimen:

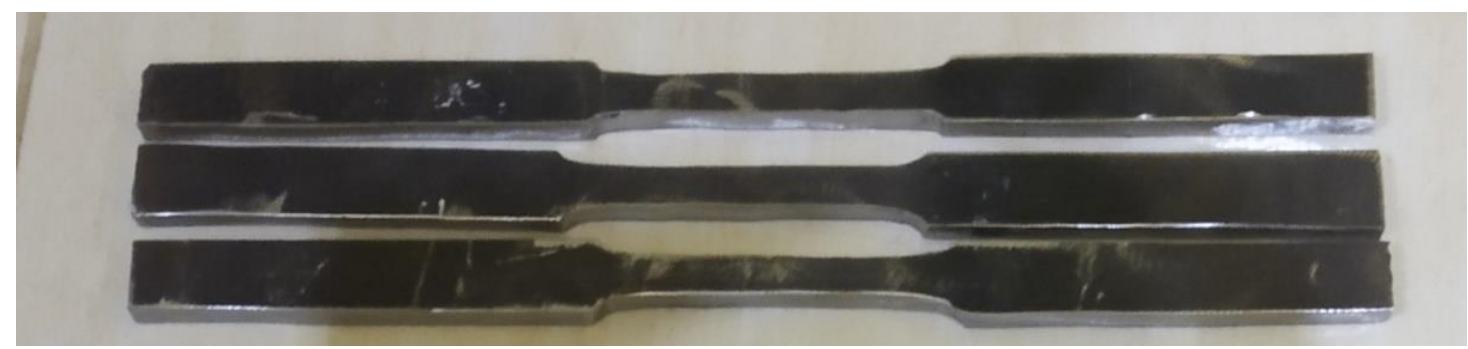

Figure 3 : 1.0038 Carbon Steel Tensile Test Specimen (Without Welding)

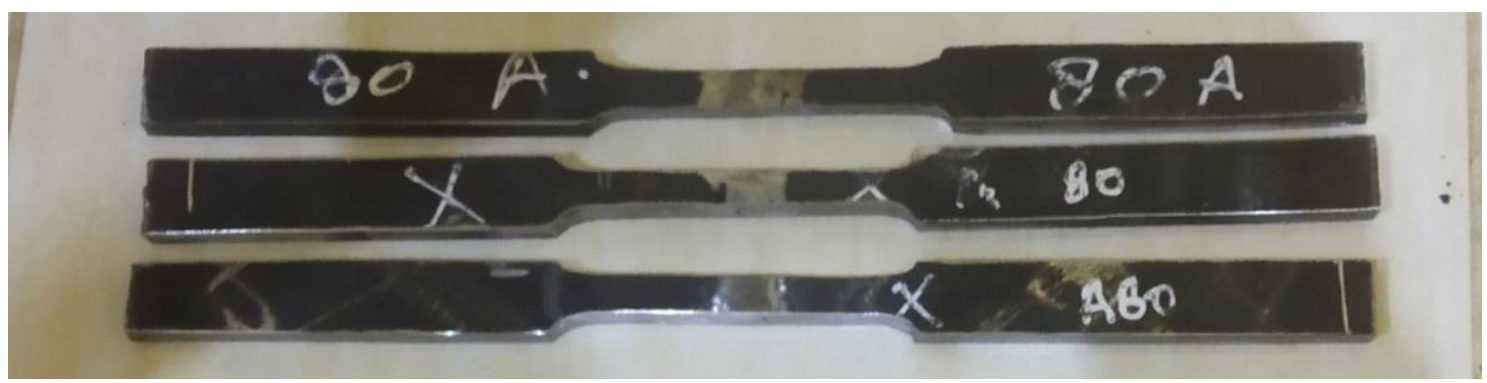

Figure 4 : Specimens of Tensile Testing for Carbon Steel 1.0038 with Welding Current of 80 Ampere 


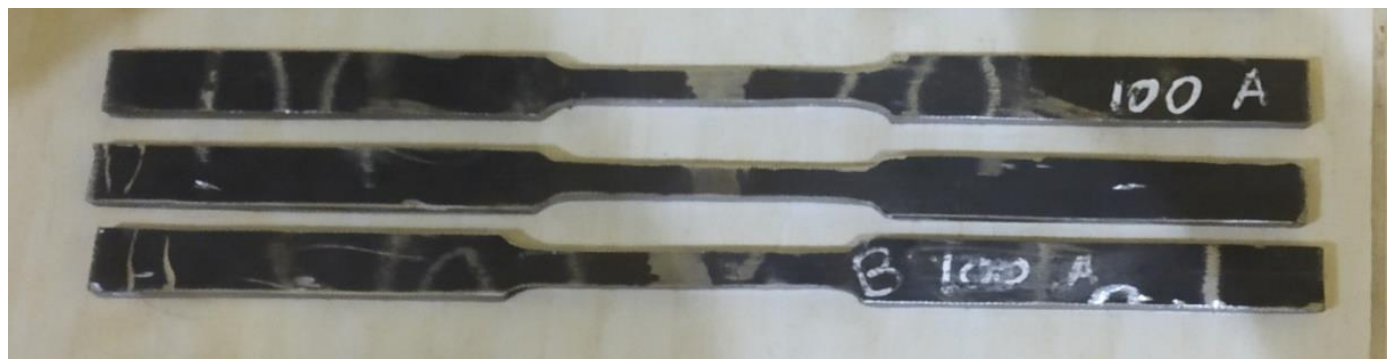

Figure 5 : Specimens of Tensile Testing for Carbon Steel 1.0038 with Welding Current of 100 Ampere

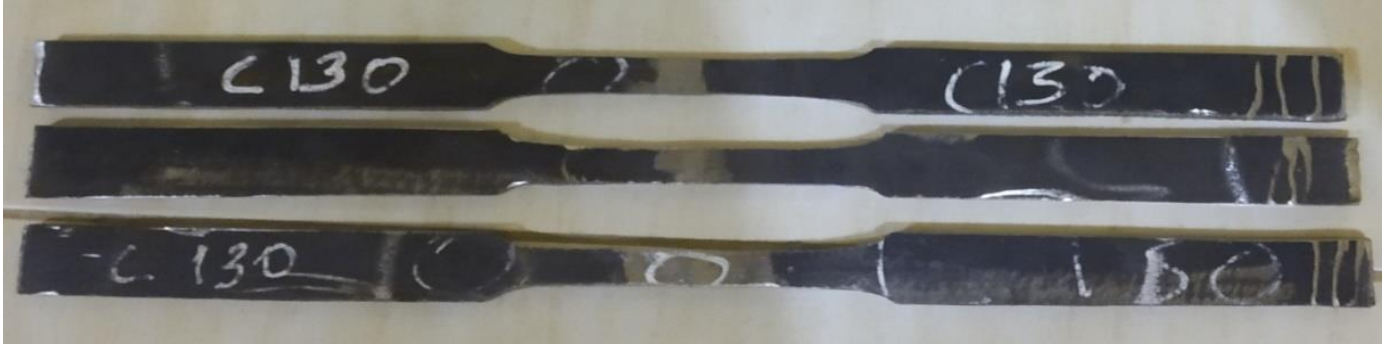

Figure 6 : Specimens of Tensile Testing for Carbon Steel 1.0038 with Welding Current of 130 Ampere

Tensile test is carried out for 3 times of testing for each type of specimen. Each type of specimen has 3 materials tested with the Universal Testing Machine. Tensile testing is a test carried out by giving a load on the material until a failure or break occurs. If an object is given a pull force, the object will experience an extension in length which happens because there is a relationship between the application of the attractive force and the increase in length. If the force per unit area is called stress and the increase in length is called strain, then this relationship is expressed as a stress-strain graph.

In the tensile test, the load is given continuously and slowly and constantly, at the same time observing the elongation experienced by the specimen and a stress-strain curve is generated. To determine the value of the tensile strength of the material $(\sigma)$ the value of the maximum force $(\mathrm{F})$ is divided by the cross-sectional area $\left(\mathrm{A}_{0}\right)$ (Equation 1). After determining the value of the tensile strength then determining the strain value (E) by means of the final length of the material after testing $\left(\mathrm{L}_{\mathrm{i}}\right)$ minus the initial material length before the tensile test (L0) divided by the length of the initial material $\left(\mathrm{L}_{0}\right)$ then multiplied by $100 \%$ (Equation 2) . Last, to determine the value of the modulus of elasticity of the material $(\mathrm{E})$, the amount of tensile strength $(\sigma)$ is divided by the strain that occurs in the material $(\varepsilon)$ (Equation 3) [25].

$$
\begin{aligned}
& \sigma=\frac{F}{A_{0}} \ldots \ldots \ldots \ldots \ldots \ldots \\
& \varepsilon=\frac{L_{i-L_{0}}}{L_{0}} \times 100 \% . \\
& E=\frac{\sigma}{\varepsilon} \ldots \ldots \ldots \ldots \ldots \ldots
\end{aligned}
$$

\section{RESULTS AND DISCUSSION}

Tensile test result data is obtained by testing all test specimens so that a graph of the tensile test results is obtained which is attached to the attachment. Tests carried out on carbon steel with code 1,0038 without treatment will be carried out 3 times of the test, carbon steel with code 1,0038 with welding using a current of $80 \mathrm{~A}$ for 3 times of the test, carbon steel with code 1,0038 with welding using a current of $100 \mathrm{~A}$ as much as 3 times testing and finally for carbon steel with code 1.0038 by welding using a current of $130 \mathrm{~A}$ for 3 times and the total of all tests was 12 times. For the results of these tests, the data is written in table 2. 
Table 2 : Test Result Data

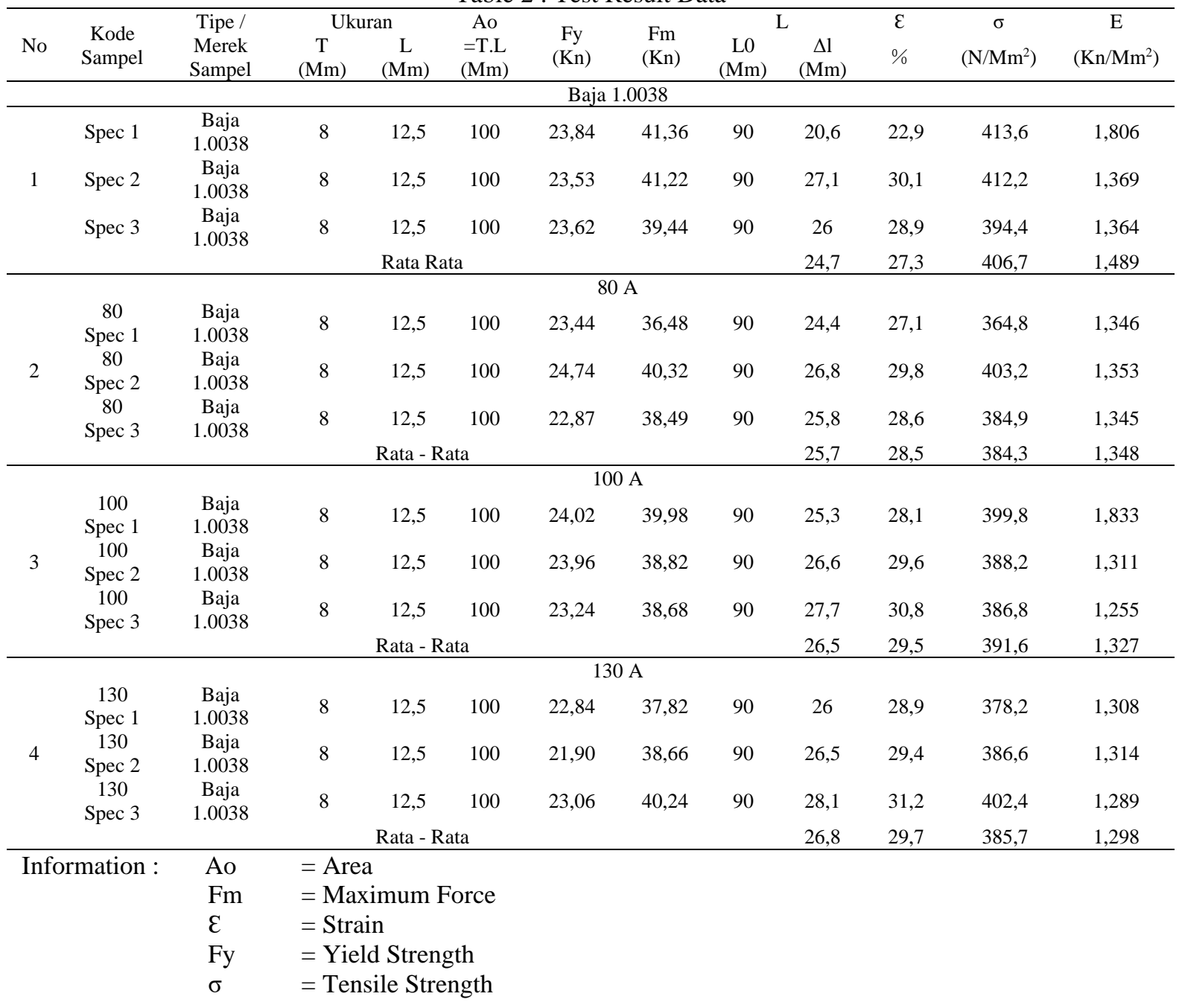

Based on table 2 the following graph of average tensile strength of each test specimen:

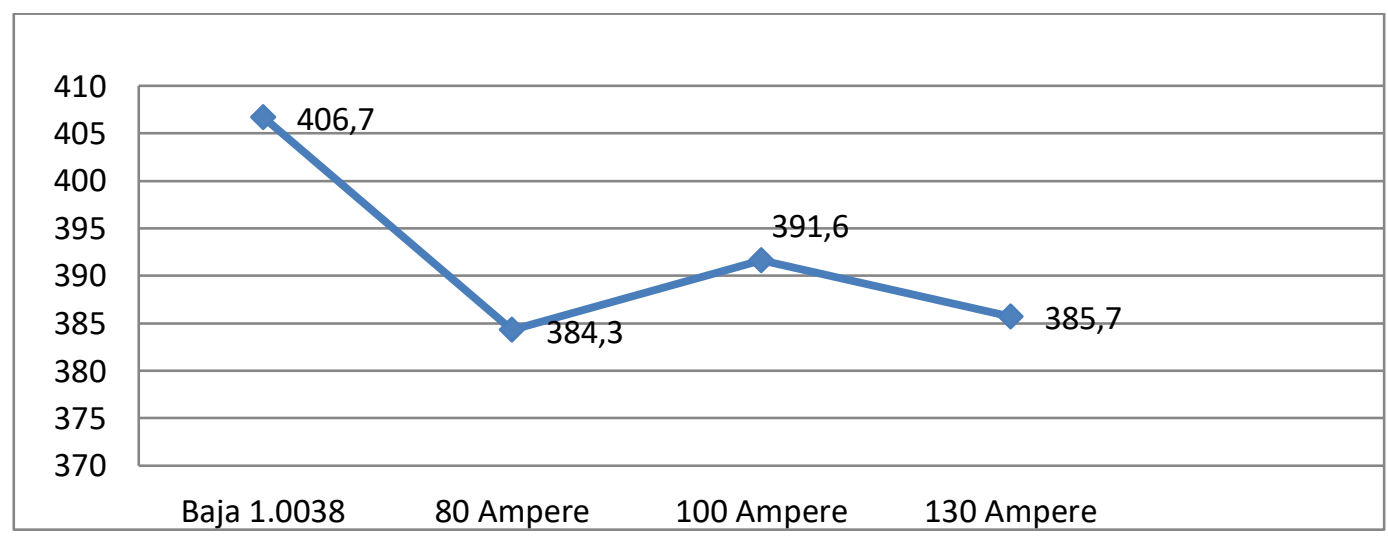

Figure 7 : Comparison Chart of Specimen Tensile Strength

Based on the graph in the figure, it can be seen that each specimen has different tensile stress, strain, and modulus of elasticity. In addition, this graph is the comparison of the average tensile strength of each specimen. Thus it is concluded that the current strength and the tensile stress are inversely proportional, where the higher the welding current used, the lower the tensile stress and vice versa, the lower the welding current used, the higher the tensile strength produced. 
Based on the analysis that has been carried out, the tensile strength of the control specimen has a tensile stress value of $406.73 \mathrm{~N} / \mathrm{mm}^{2}$, for the strain it has a value of $27.3 \%$ and a modulus of elasticity of 1.489 $K N / \mathrm{mm}^{2}$ And the results of the tensile strength with a current of 80 A have a tensile strength of 384.3 $\mathrm{N} / \mathrm{mm}^{2}$, then for the strain it has a value of $28.5 \%$ and the modulus of elasticity is $1.348 \mathrm{KN} / \mathrm{mm}^{2}$. The current of $100 \mathrm{~A}$ has a tensile strength of $391.6 \mathrm{~N} / \mathrm{mm}^{2}$, then for the strain it has a value of $29.5 \%$, and the modulus of elasticity is $1.327 \mathrm{KN} / \mathrm{mm}^{2}$. Finally, the tensile strength with a current of $130 \mathrm{~A}$ has a tensile strength of $385.7 \mathrm{~N} / \mathrm{mm}^{2}$, and the strain value is $29.7 \%$, and the modulus of elasticity is $1.298 \mathrm{KN} / \mathrm{mm}^{2}$.

\subsection{Steel Specimens 1.0038}

This specimen does not go through heat treatment in the welding process, it aims to be a control for specimens that receive welding treatment, for the control specimen has an average tensile strength value of $406.7 \mathrm{~N} / \mathrm{mm}^{2}$. The value of the tensile strength is the highest value of all tensile testing specimens, this can occur because in the control specimen there is no welding treatment is given before the test so that the test specimen does not experience structural changes.

\subsection{Tensile Test Specimens with 80 A of Welding Current}

In this specimen, the SMAW welding process was carried out with the magnitude of current about $80 \mathrm{~A}$ which was carried out on 3 specimens. Furthermore, after welding the specimen will be formed according to the shape of the tensile test specimen and then the tensile test is carried out. After the tensile test is carried out, the first test specimen breaks in the weld joint. This happens because the metal is not melted during the welding process unevenly. Hence, after analyzing the tensile strength of the specimen with a welding current $80 \mathrm{~A}$, it is the smallest value of all test results. From the results of the tensile test, the average tensile strength of the test results with a current of $80 \mathrm{~A}$ is $384.3 \mathrm{~N} / \mathrm{mm}^{2}$. This is the lowest value among all test specimens that have been welding and this current is not suitable for being used in plate welding with a material thickness of $8 \mathrm{~mm}$. This happens because the welding process with $80 \mathrm{~A}$ of current is very difficult to control and arcs often die during the welding process, if the welder cannot control the swing during the welding process the electrodes will die in the middle of the specimen welding process. In addition, for the process of charging with the current of $80 \mathrm{~A}$ is not very suitable if it is used for $8 \mathrm{~mm}$ thick plates.

\subsection{Tensile Test Specimens with 100 A of Welding Current}

In this specimen, the SMAW welding process was carried out with $100 \mathrm{~A}$ of the current which was carried out on 3 specimens. Furthermore, after the welding process, the specimen will be formed according to the shape of the tensile test specimen and then the tensile test is carried out. From the tensile test results, the average tensile strength of the test results with a current of $100 \mathrm{~A}$ is $391.6 \mathrm{~N} / \mathrm{mm}^{2}$. This is a quite good value caused by the $100 \mathrm{~A}$ current which is included in the standard current in the welding process of plates with a thickness of $8 \mathrm{~mm}$ using the E7018 electrode. The results of the welding on this specimen are good for filling and are very good for penetration using seam $\mathrm{V}$ joints.

\subsection{Tensile Test Specimens with 130 A of Welding Current}

In this specimen, the SMAW welding process was carried out with the current of $130 \mathrm{~A}$ which was carried out on 3 specimens. Furthermore, after welding the specimen will be formed according to the shape of the tensile test specimen and then the tensile test is carried out. From the results of the tensile test, it was found that the average tensile strength of the test results with a current of 130 Ampere was $385.7 \mathrm{~N} / \mathrm{mm}^{2}$. This value is a fairly high tensile strength value because the current strength used is the highest current strength in plate welding standards with a thickness of $8 \mathrm{~mm}$ and the tensile strength value is not much different from the results of welding using a $100 \mathrm{~A}$ of current. The welding result on this specimen is good enough for filling and penetrating yet the welding result shows a welding defect in the form of an under cut and the formation of a crater at the end of the weld groove.

\section{CONCLUSION}

Based on the analysis and discussion of the data obtained during testing, it can be concluded that the welding process using current of 80A, $100 \mathrm{~A}$, and $130 \mathrm{~A}$, and electrode E7018 with a diameter of $3.2 \mathrm{~mm}$ will affect the tensile strength of low carbon steel welding. The higher the welding current used, the lower the tensile strength of the material. The welding process using $100 \mathrm{~A}$ of current produces the highest tensile strength value of all test specimens that are given welding treatment, which is $391.6 \mathrm{~N} / \mathrm{mm}^{2}$, and the welding results are good for the filling and penetrating process. So this indicates that the most suitable welding current for the plate welding process with a material thickness of $8 \mathrm{~mm}$ is to use a current of $100 \mathrm{~A}$.

Journal homepage: http://teknomekanik.ppj.unp.ac.id

DOI: https://doi.org/10.24036/tm.v3il.5572 


\section{REFERENCES}

[1] Wiryosumarto, Harsono Dan Okumura, Toshie, Teknologi Pengelasan Logam. $8^{\text {th }}$ Ed. Jakarta: PT Pradnya Paramita, 2000.

[2] Nikko Welding Hanbook. Nikko Steel Welding Consumables And Procesess. Volume 2. 2013

[3] S. Hestukoro, I. Roza, And D. Morfi Nst, Process Analysis Of High Speed Steel Cutting Calculation (HSS) With S45 C Material On Universal Machine Tool. Int. J. Innov. Sci. Res. Technol., Vol. 3, No. 1, 2018.

[4] Nusulul Huda, Jasman, Pengaruh Kuat Arus Terhadap Uji Tarik Material Baja Karbon Rendah Menggunakan Metal Inert Gas (Mig). Ranah Research. Volume 2, Issue 1, November 2019.

[5] Cary, H.B, . Modern Welding Technology. $4^{\text {th }}$ Ed. New Jersey: Prentice Hall, 1998.

[6] A. H. H. Ahmad Yani1, Junaidi2, M. Irwanto3, Optimum Reactive Power To Improve Power Factor In Industry Using Genetic Algorithm. Int. J. Electr. Eng. Comput. Sci., Vol. 14, No. 2, Pp. 751-757, 2019.

[7] Indra Roza Junaidi, Weriono, Irrigation Water Debit Analysis That Will Be Used On Micro Power Plant In SEI . Rampah Sub-District Of Serdang Bedagai Regency, Int. J. Innov. Sci. Res. Technol., Vol. 3, No. 1, 2018.

[8] Kou, S., Welding Metallurgy. $1^{\text {st }}$ Ed. Singapore: Jhon Wiley And Sons. 1987.

[9] Daryanto. Keselamatan Dan Kesehatan Kerja Bengkel. Jakarta: Rineka Cipta. 2007.

[10] Ferry Budhi Susetyo, Ja'far Amirudin, Studi Karakteristik Pengelasan Smaw Pada Baja Karbon Rendah St 42 Dengan Elektroda E 7018. $1^{\text {st }}$ Ed. Jakarta : Jurnal Konversi Energi Dan Manufaktur UNJ. Oktober 2013.

[11] S. H. A. 3 A. B. 4 E. S. H. Junaidi1, Effect Of Variation Of Point Welding Electric Flow On Low Carbon Steel, Medium Carbon Steel And High Carbon Steel Sheielding Metal Arc Welding (Smaw), Teknologi, Vol. 19, No. 6, Pp. 1-4, 2019

[12] Gharibshahiyan, E., Raouf, A.H., Parvin, N., Rahimian, M.. The Effect Of Microstructure On Hardness And Toughness OfLow Carbon Welded Steel Using Inert Gas Welding, Materials \& Design, Vol. 32, No. 4, 20422048, 2011. Doi: 10.1016/J.Matdes.2010.11.056.

[13] Sakthivel, T., Sengar, G.S., Mukhopadhyay, J. Effect Of Welding Speed On Microstructure And Mechanical Properties Of Friction-Stir-Welded Aluminum, The International Journal Of Advanced Manufacturing Technology, Vol. 43, No. 5-6, 468-473, . 2009 Doi: 10.1007/S00170-008-1727-7.

[14] Sahin, M.. Joining With Friction Welding Of High-Speed Steel And Medium-Carbon Steel, Journal Of Materials Processing Technology, Vol. 168, No. 2,202-210, 2005. Doi: 10.1016/J.Jmatprotec.2004.11.015.

[15] Ferry Budhi Susetyo, Ja'far Amirudin, Studi Karakteristik Pengelasan Smaw Pada Baja Karbon Rendah St 42 Dengan Elektroda E 7018. $1^{\text {st }}$ Ed. Jakarta : Jurnal Konversi Energi Dan Manufaktur UNJ. Oktober 2013.

[16] Sunaryo, Hery. Teknik Pengelasan Kapal. $2^{\text {nd }}$ Ed, Jakarta: Direktorat Pembinaan Sekolah Kejuruan. 2008.

[17] A. V. Adedayo, S. A. Ibitoye And O. A. Oyetoyan, Annealing Heat Treatment Effects On Steel Welds, Journal Of Minerals And Materials Characterization And Engineering, Vol. 9, No. 9, 2010, Pp. 547557.

[18] A. V. Adedayo, S. A. Ibitoye And O. O. Oluwole, Tempering Heat Treatment Effects On Steel Welds, Journal Of Minerals And Materials Characterization And Engineering, Vol. 10, No. 8, 2011, Pp. 755764.

[19] R. S. Funderburk, Key Concepts In Welding Engineering, Welding Innovation, Vol. 15, No. 2, 1998

[20] Talabi, S.I.A, Owolabi, O.B.Effect Of Welding Variables On Mechanical Properties Of Low Carbon St eel Welded Joint. Journal Of Advances In Production Engineering \& Management. Vol.9. No.4. 2013. Pp.181-186. Http://Dx.Doi.Org/10.14743/Apem2014.4.186.

[21] Karadeniz, E., Ozsarac, U., Yildiz, C. The Effect OfProcess Parameters On Penetration In Gas Metal Arc Welding Processes, Materials \& Design, Vol. 28, No. 2,649-656, 2007. Doi: 10.1016/J.Matdes.2005.07.014. 
[22] T. V. Raja, C. P. Sharma And A. Sharman, Heat Treatment Principles And Techniques, Prentice Hall Of India Private Limited, New Delhi, 1999, P. 243.

[23] Kim IS Et Al. An Investigation Into An Intelligent System For Predicting Bead Geometry In GMA Welding Process. J Mater Process Technol. 2005.

[24] Jasman, J., Irzal, I., Adri, J., \& Pebrian, P.. Effect of Strong Welding Flow on The Violence of Low Carbon Steel Results of SMAW Welding With Electrodes 7018. Teknomekanik, Vol 1(1), 24-31. Agustus. 2018.

[25] Bondan T. Sofyan, Pengantar Material Teknik. 1 ${ }^{\text {st }}$ Ed. Jakarta: Salemba Teknika.2010. 